\title{
«Bases of social regulation and public relations» subject: MGSU teaching experience
}

\author{
Igor Andreev ${ }^{1, *}$ \\ ${ }^{1}$ Moscow State University of Civil Engineering, Yaroslavskoye sh. 26, Moscow, 129337, Russia
}

\begin{abstract}
The report presents the author's teaching experience in Moscow State University of Civil Engineering (MGSU) in 2014 - 2017 of a new subject aimed to consolidate the information which is usually «dispersed» between courses of public relations, management, philosophy, sociology, etc. In particular, the author expresses his point of view concerning the most optimal structural organization of a training material for this discipline, considers the most successful, in his opinion, methodical practices, marks some features of the discipline understanding by students and their achieved results in study. Considering the training material provided in the first part of this discipline - «Bases of social regulation», the author suggests to make the central, «recurrent» problem of the section the question of social planning in urban policy and especially - the social aspects in development and implementation of the smart city concept. In the second part of the discipline - «Public relations» - the author considers reasonable to pay special attention (apart from the general-theoretical communication problems reviewing) to practical questions of establishment of trust relationships between town-planners and social groups similar to different components of a creative class. The author comes to a conclusion that the teaching methods of this subject in construction higher education institutions should create for students an integral view of the democratically understanding processes for social planning in town-planning, inseparably connected with different forms and methods of social communication.
\end{abstract}

\section{Introduction}

The new subject - «Bases of social regulation and public relations» was included for the curriculum of second-year MGSU bachelor program degree in «Town planning» (Institute of construction and architecture) in 2014. This action, certainly, should be considered as an understanding by the institute directors the highly complex nature of the town-planner engineer activities, which assuming the consideration of diversiform factors in technical, culturological, social and psychological aspects. The curriculum of «Town planning» degree in MGSU in general differs in much more academic hours dedicated for social and humanitarian disciplines: so, for example, there are 4 times more classes of sociological and

*Corresponding author: andreev-i-v@yandex.ru 
psychological subjects, than at the specialties «Industrial and civil engineering» and «Thermal power plant».

It is supposed that the purpose of this course is development of several common cultural and practical competences for students designed to play an important role in successful implementation of the student's professional activity. The basis for common to all cultural competences is ability to analyze the socially important problems and processes, to understand world outlook and philosophical problems. This competence is created in the course of all course sections study. The subject of the section «Social regulation in conditions of town-planning conflict», where a lot of attention is paid to the inter-ethnic interaction problems in the urban environment, can help to improve a student's ability to work successfully in collective, to be tolerant to social, ethnic, confessional and cultural distinctions. And the student's received knowledge about the way to manage engineering, and social aspects during the town-planning activities, shall promote formation of such important practical competence as knowledge of a complex of the humanitarian, naturalscience and application-oriented disciplines necessary for development of urban policy.

The author of the present report in 2014 - 2017 gave lectures and gave a practical training in this discipline. He developed the working program of the course, the abstract of lectures, methodical recommendations and a workbook for carrying out the practical training. For the past two years there was gained some experience of teaching this subject allowing making preliminary conclusions concerning:

- contents and structure of the course;

- reasonability of this discipline in construction higher education institution;

- the most successful methodical implementation;

- student's learning style for the discipline and their results during the study process.

In our opinion, the analysis relevance of this experience is in addition caused by the fact that in one other higher education institution of Russia the disciplines with the similar name aren't taught at all. Therefore the author expects that his report can promote the attention of pedagogical community to the highlighted question of consolidation in MGSU within one discipline the information which is usually «dispersed» between courses of public relations, management, philosophy, etc.

The author found valuable material on social aspects of town-planning policy in works by J. Kotkin [1], D. Owen [2], W. Rybczinski [3]. Important information on smart city concept and creative class concept is presented in works by T. Monfaredzadeh and R. Krueger [4], A. Vanolo [5], R. Florida [6-8]. The author used to develop the course works on public relations by R.L. Heath [9], S.C. Duhé [10], A.A. Betteke van Ruler and D. Verĉiĉ [11].

\section{Methods}

The methods used in the research course had the following purposes: student's interest and motivation identification in studying discipline; student's knowledge level assessment of the studying material.

For implementation of the first of these purposes there was used a questionnaire survey, where, in particular, students could valuate the importance of the gained knowledge for their future professional activity, tell which part of subject interesting for them was not described sufficiently in a training material, could give their feedback of the teaching technique, etc.

The second objective was achieved by means of: evaluation exercises made by students during practical trainings; studying of the students testing results showing the absorbed knowledge of each discipline sections; group valuation of the reports quality, presented at 
scientific conferences, and feedback of the role plays during the business games; a final all course examination of the students.

\section{Results}

The working program of the discipline is actualized annually. From our point of view, the following study curriculum plan which was already implemented in the last autumn semester of 2016 - 2017 academic years is the optimum.

The social planning bases and the town-planning design aimed to create a socially comfortable urban environment are studied in the first section - «Social regulation in town planning». Students get acquainted with the technique of special social diagnostic testings as a part of preproject research and development works and engineering investigations. This problem is concretized in the second section devoted to different social technologies practices as part of the social regulation process. In particular, special attention is paid to problems of social engineering and social and technological algorithms development. The content of the third section is currently important; it is devoted to social regulation questions reviewing in situations of town-planning conflict. The city is considered here as an epicenter of different social conflicts in consequence of turf battle, resulting in segregation and marginalization of separate groups in urban society. Also there is analyzed such challenging phenomenon as gentrification and its social consequences. Students receive extensive information concerning the town-planning conflicts reasons and a typology, methods of its prediction and overcoming. In the fourth section students get acquainted with theoretical bases and historical experience of public relations. In the fifth section there are reviewed different types and forms of public relations, where the special attention is paid to presentation of the communication theory bases. Students also master application-oriented skills of PR-programs compilation, receive initial knowledge about specifics of the implementation of these programs and assessment of their efficiency. Logical continuation of this material is the information about different forms of townplanning conflicts PR-attending studied in the final (sixth) section. Students get acquainted with theoretical outputs and hone their practical skills of involvement in public listening on town-planning projects and holding different events with mass media communications.

As you can see at the course name and at the subject plan, actually it is about teaching two areas of knowledge that allows to draw a conclusion on reasonability of structuring a training material to two primary partitions. At the same time it is obvious that these areas of knowledge have the general theoretical-methodological base, its goal is to find common factors of the purposeful impact on different social groups aiming to change of their behavior and their living conditions in the direction planned by the influence party. At this presentation way these common factors don't «reach» the social and philosophical level, and concentrate on social and technological influence aspects and preferentially on social algorithms (sets of the specific sequential steps) search which have high probability to achieve the goal.

As an important positive moment it is necessary to mark that first year students acquired the certain methodological approaches to comprehension of discipline content provided in courses of sociology, sociology of town planning and psychology of social interaction.

And now let us have a closer look at the most interesting, in our opinion, methodical aspects for teaching of this discipline.

Part 1 bases of social regulation. At an introductory lecture of this part the professor refreshes knowledge of students from town planning sociology course connected to a problem of socially reasonable urban development, and all types of social regulation are designed to put into action its base characteristics. In a historical part of an introductory lecture we also bring up to date the actual methods of implementation of these or those 
socially reasonable urban development principles shown by E. Howard, Le Corbusier, J. Jacobs, V. A. Ilyichev's theoretical and practical activities, school of «new urbanism», etc. [1-3].

At the next lectures students receive knowledge about main points of social planning in urban policy, with the strong accent to the progressiveness of this methods and its originality in the home country conditions. Thereby students can see the perspective of new discovers, creative personal fulfillment during their study of all new aspects of social planning taking into account the Russian specifics.

The professor aims to communicate to students a key idea of social planning as method basing not on plans of playgrounds and constructions at the terrain, but on the social problems facing by the population of this terrain and on some search of town-planning solutions of these problems $[4,5]$.

The central subject of the first part of the course is the problem of the Russian cities social planning development oriented on their transformation into smart cities. In the lecture material there are explained different aspects of the smart city concept basing on the system of information communications development allowing to optimize a functioning of different structural components of economic, housing-and-municipal, sociocultural and administrative activity. In this regard attention of students is drawn to a phenomenon of the creative class rapid growth and its social role increase showing the whole set of nonstandard requirements to the urban environment which part can be implemented only in the smart cities conditions [6-8].

Self-guided students work over a problem of social aspects of the practical implementation of the smart city concept from our point of view can include three following stages.

At the first stage several students have the task to present an essence of the smart city concept, the main content of discussions about a phenomenon of a creative class, and also the most successful experience of implementation of the smart city concept, for example, in Vienna, Helsinki, Oulu, Barcelona, Cologne, etc. Students report their results at a joint scientific conference.

At the second stage students will be divided in several research groups (teams) on the principle of belonging of their participants to one large city or to one region. Each of students develops one aspect to make their hometown closer to the optimum smart city model (as, for example, in the concept of smart city Oulu - the smart environment, smart transport, a smart life style, etc.), accenting at the same time any specific requests, expectations and alarms from different groups of citizens. At the same time for the complete identification of the specified social aspects of development and implementation of the smart city concept the professor recommends to students to involve a wide range of methods to collect the primary sociological information, including the analysis of materials of regional mass media, questioning of participants of social networks, interviewing of activists of city public organizations and movements, observation, etc.

The final stage of the group work is the synthesis of the achieved results in the form of the general reports on these cities presented and discussed at the next joint conference which can be referred to scientific and practical category.

At the final class of the first course part students arrive at a conclusion of the need of involving as much of citizens as possible to process of social planning. But thereby attention of students is drawn to a problem of search of the most effective forms of communication with citizens, with different types of city communities, with public. The idea of the maximum democratization of a social planning process is therefore a medium between the both course parts.

Part 2 public relations. At an introductory lecture of this section it is emphasized that relevance of public relations problematic is caused by development needs of all public life 
areas - economic, political and sociocultural. Thereby students are leaded to conclusion that knowledge in PR is currently important and will be demanded not only in townplanning activities, but also far beyond its limits, in particular, in situations when their effective involvement in political life free from manipulative influence of media is necessary. In this regard it is important to mark that a discussion on a practical class of a problem of ideological, social and psychological mechanisms of manipulation with mass consciousness under the totalitarian conditions which different aspects were described in such original works as J. Orwell's novel «1984» and the movie directed by M. I. Romm «Ordinary fascism» have a serious emotional impact on students. Discussing the reports on these works students come to a conclusion that the manipulative methods used in totalitarian societies didn't become completely the thing of the past, it is still practicing today in other forms in ideological and political campaigns at all levels, including the global one. In September, 2016 the study of these questions was coincident with a parliamentary election campaign, and it was nice to see that student could recognize a variety of manipulative methods used by a certain part of political parties and their candidates.

We acquaint students with the general communication theory as the following step after the «introductory» lessons of this section. At the lecture students get acquainted with theories of G. Lassuell, C. Shannon and W. Weaver, V. Shram and Ch. Osgood, V. P. Morozov, P. Lazarsfeld; receive a knowledge about principal components of communicating process and the nature of communication barriers $[9,11]$. They also can put their knowledge into practice at a practical lesson during their work on the analysis of the specific communication barriers context (with examples from practice or from fiction), on unsuccessful messages «rewriting», on effective listening technique.

At the other practical lesson on the theory of communication, the students group in different teams and work on the technique of direct communication with target audiences, showing their skills of new «fictional» construction organizations presentation, holding the briefings and press conferences on the subject of their activities.

The important subject of a lecture lesson is the technique of the public image creation for the construction organization and its directors. Also the concept «brand» (its mission, classification of its attributes, a technique of creation of a brand consumer value) is studied.

The continuous scientific conference on «City Branding» gains a reputation of an event of interesting form and content. In the provided reports students described the general regularities and local specifics of city brand formation, presented different suggestions about the city brand improving methods. It is necessary to mark that for students the most authoritative paper on common problems of city branding is D. Vizgalov's book [12]. In this book they find a compendium of data concerning the theories by Russian and foreign authors of the «city brand» concept, features of formation and promotion of a city brand, its influence on development of a city identity and on a target audiences behavior. These data form a basis of the first, «theoretical» report presented at a conference. A big part of the conference time is devoted to performances of the student's presentations of their hometowns current brands analysis and perspectives of its improvement. The typical questions raised in these reports are the problems of identification of a city brand, determination of the PR campaigns branding target audiences, the principles of selection of the most significant objects, events and achievements of the city designed to form the PR campaign frame. Also such complex psychological problems of branding PR campaign as formation of the necessary dominants and neutralization of the dominants which blocks the optimum perception of the city by target audiences are discussed. In this regard it was marked that the ideal branding PR campaign should create the given dominant in target audiences mass consciousness and at the same time should not be seen as an advertising. Often the opened problem is the strong and weaknesses of the city websites. It is natural 
also that students town-planners in the performances pay the main attention not to the social and psychological, but to object and practical aspects of a city brand formation, in details analyzing the unsuccessful architectural and town-planning concepts which are present at their hometowns and offering the alternative solutions.

The final part in the practical work is the business game «Town-planning Questions Public Listening». The worthwhileness of this game is caused by need «to rehearse» during the event the steps of the operational procedure which a legislator defines as an «obligatory» component for the process of town-planning projects development and implementation [13, art. 28] and where therefore future engineers-town-planners should participate on repeated occasions. We can recommend to the professor to emphasize the humanistic aspects of the public listening which are carried out «for respect for human right on favourable standard of living» as it is noted by a legislator [13, art. 28]. This form of the study process provides to the students opportunity to practice and improve the following skills that are expected to be very useful in their professional activity: the ability to present the core of a town-planning project to wide audience in comprehensible way, the ability to feel mood of an audience and to find a contact with it, the skill to react quickly to questions from an audience. And, as we know, according the theory of public relations these qualities are remarkably important for the PR specialist.

It is more reasonable to carry on the game for several students groups together and not only for the one. It can push the number of the participants of the event closer to the reality. The implementation of this training form includes the following main stages.

1) Determination, according to students' opinion, key figures of the listening - «the representative of local self-government institutions», «customer", $2-3$ «social activists» (and one or two of them must play a role of the «creative class» representatives), $1-2$ «experts», «moderator».

2) The preliminary preparation which should be done by all sides of this role play. In particular, «customer» during $1-2$ weeks shall inform all students on the project, by providing them all necessary drawings, photos, loads calculations, etc. «Experts» prepare the deep analysis of the materials provided by the customer. «Social activists» investigate the students opinion about the project, basing on the questionnaire concerning assessment by «population» of this document's several principal parameters; after studying of questionnaire data the «activists» prepare the final abstract fixing a «population's» opinion on the strong and feeble and not clear enough to the citizens parts of the project and also the ideas to improve it.

3) Acquaintance by the participants of the game with the recommendations according to the theory of public relations in relation to this kind of actions. (These recommendations can be explained by one of the students in the report form on a practical class before the «public listening»). In particular, the «customer» should respect an opinion of citizens, including alternative opinions, he should be open to search for any compromise solutions. Considering that the audience of the «public listening» in this business game is quite prepared, so the «customer» and «experts» will have a certain psychological challenge: they should follow the rules to present the project in understandable way for the mainstream audience, in particular, with limited use of digital media, special terminology, etc; but it is necessary to remind about this rule and to suggest to practice it before.

4) Actually the procedure of «public listening» is organized according to the following approximate plan:

- a «moderator» speech on subject, purpose and order of holding event (up to $5 \mathrm{~min}$.);

- a speech of «the representative of the local self-government institutions» on the importance of the discussed project in the general town-planning context, ecological and social situation in the region (up to $5 \mathrm{~min}$.); 
- a «customer» speech presenting the project content (up to $15 \mathrm{~min}$.);

- «experts» speeches giving their professional evaluation of the strong and weak parts of the project (up to $15 \mathrm{~min}$.);

- speech of one or two of "social activists» giving the opinion of the neighboring quarters habitants on the project, according to performed relevant sociological study, conversations, meetings etc. (up to $10 \mathrm{~min}$.);

- questions and speeches of habitants and responses of the corresponding parties (up to 25 min.);

- the issuing of the final document coordinating with audience, placing on record the achieved results and arrangements (up to $15 \mathrm{~min}$.).

5) Discussion of positive and negative aspects of the actions from all sides of the listening (it should be carried out on the following practical lesson that allows to participants to detailed evaluate their input to the event).

\section{Discussion}

Being a member of methodical council of Institute of construction and architecture, the author of the present report received from the colleagues various recommendations about the content and teaching methodology for this discipline, in particular, concerning the focus on a problem of the town-planning conflicts as one of the most modern and important phenomenon of town-planning activities. In his turn, the author drew the attention of colleagues to a practical tendency of the course, what should promote the distribution of time between lectures and practical trainings in favour of the last.

Students considered reasonable including of this discipline in their curriculum. As one of the most important advantages of this course they mark the skills of investigation and understanding the interests and expectations of different social groups in the town planning process. Thereby, students suppose that the results of their future professional activity will be more demanded and competitive.

It is possible to state also that material of the second part of course - «public relations» - has much more social and psychological perspective than material of the previous part. This circumstance causes the increasing of student's interest in the studied discipline during the course (the special preference which is given by students to psychological material is well known to all teachers of social and the humanities science).

Students demonstrated eagerness, enthusiasm and creativity preparing the theoretical conferences at the institute and university levels, presenting their practical works on mastering of different forms of communication with the public and mass media. Some of the most interesting students' reports were presented at the international scientific conferences "Integration, Partnership and Innovations in Construction Science and Education", the participants received good references and its papers were published.

The test result passed by the students also showed their good knowledge of the discipline.

\section{Conclusions}

We suppose that the position described above allows us to state the following:

- Integration of the course of «Basis of social regulation and public relations» to MGSU proved its value. The course allows to create in students consciousness an integral view of democratically understood processes of social planning in the town-planning area, inseparably connected to the different forms and methods of social communication. 
- Social aspect of the smart city development is one of the main and the most important problem for whole course. In its first part we investigate the social determinants of a smart city phenomenon and, in particular, some social expectations of certain social groups («the creative class», etc.) in construction area, and also the town-planning decisions oriented to satisfy these expectations. And in the second part of the course students master theoretical methods and practical skills for the effective communication with these groups.

\section{References}

1. J. Kotkin, The city: a global history (Modern Library, N.Y., 2005)

2. D. Owen, Green metropolis: why living smaller, living closer, and driving less are the keys to sustainability (Riverhead Books, N.Y., 2009)

3. W. Rybczinski, Makeshift metropolis. Ideas about cities (Scribner, N.Y., L., Toronto, Sydney, 2010)

4. T. Monfaredzadeh, R. Krueger, Procedia Eng. 118, 1112-1118 (2015)

5. A. Vanolo, Futures 82, 26-36 (2016)

6. R. Florida, The rise of the creative class. And how it's transforming work, leisure, community and everyday life (Basic Books, N.Y., 2002)

7. R. Florida, The flight of the creative class. The new global competition for talent (Harper Business, Harper Collins, N.Y., 2005)

8. R. Florida, Who's is your city? How the creative economy is making where to live. The most important decision of your life (Basic Books, N.Y., 2008)

9. R.L. Heath, Encyclopedia of public relations (Thousand Oaks, California, 2005)

10. S.C. Duhé, Mass media and public relations (Peter Lang cop., N.Y., 2007)

11. A.A. Betteke van Ruler, D. Verĉice, Public relations and communication management in Europe (Mouton de Gruyter, Berlin, N.Y., 2004)

12. D. Vizgalov, Brending goroda (Institut economiki goroda, Moscow, 2011)

13. Town-planning code of the Russian Federation (last edition of 03-07-2016). URL: http://www.cis-legislation.com. 